\title{
PARTISIPASI PASIEN MENGAMBIL KEPUTUSAN KLINIS DALAM KEPERAWATAN
}

\author{
Elsya Fitri Syofian \\ elsyafitrisyofian93@gmail.com
}

\begin{abstract}
ABSTRAK
Pengambilan keputusan klinis memerlukan interaksi antara perawat dengan pasien. Perawat harus mengikutsertakan pasien dalam pengambilan pengambilan keputusan, dikarenakan hal tersebut termasuk dalam hak pasien. Untuk dapat menentukan keputusan klinis, perlu adanya kemampuan perawat dalam berpikir kritis. Berpikir kritis dapat melandasi bagaimana perawat dalam mengidentifikasi dan mempertimbangkan keputusan terbaik dalam membantu pasien untuk menentukan keputusannya. Keterlibatan pasien merupakan inti dari proses partisipasi keperawatan, sehingga pasien dalam proses keperawatan menjadi penting dalam penentuan kualitas dan efektifitas dalam pelayanan asuhan keperawatan. Dengan mengambil keputusan klinis yang mengikutsertakan pasien, maka akan mudah untuk menyelesaikan masalah tertentu dengan pilihan-pilihan keputusan yang terbaik.
\end{abstract}

Kata kunci: Pengambilan keputusan, keputusan klinis, berpikir kritis.

\section{Latar Belakang}

Perawat merupakan salah satu tenaga kerja kesehatan yang terpenting di rumah sakit karena selain jumlahnya yang dominan juga merupakan profesi yang memberikan pelayanan kesehatan dengan terus menerus selama 24 jam kepada pasien setiap hari. Oleh karena itu pelayanan keperawatan sebagai bagian integral dari pelayanan kesehatan jelas memiliki kontribusi yang sangat menentukan kualitas pelayanan di rumah sakit. Sehingga setiap upaya untuk meningkatkan kualitas pelayanan rumah sakit harus juga disertai upaya untuk meningkatkan kualitas pelayanan keperawatan (Yani, 2007).

Mutu asuhan keperawatan menjadi alat utama menjaga kepercayaan pelanggan pelayanan. Asuhan keperawatan bermutu dilakukan dengan meningkatkan 
kemampuan berpikir kritis perawat dalam melakukan proses keperawatan. Pelayanan keperawatan didasarkan pada pendekatan pengambilan keputusan yang dapat ditingkatkan dengan berpikir kritis (Ignatavicus \& Workman, 2006).

Berpikir kritis sangat berkaitan dengan pengambilan keputusan dan penilaian klinis yang tepat. Selain menjadi komponen yang penting dalam keperawatan, berpikir kritis juga menjadi tema yang penting dalam keperawatan dikarenakan semakin kompleksnya pengambilan keputusan klinis dalam pemberian pelayanan keperawatan untuk mengatasi masalah klien dan akan terjadi risiko yang merugikan klien jika perawat melakukan kesalahan dalam membuat keputusan (Lewis. et al, 2007).

Hubungan perawat klien adalah dasar dari praktik keperawatan yang berfokus pada pasien (patient centered care). Keterlibatan pasien merupakan inti dari proses partisipasi keperawatan, sehingga pasien dalam proses keperawatan menjadi penting dalam penentuan kualitas dan efektifitas dalam pelayanan asuhan keperawatan.

Pengambilan keputusan klinis memerlukan interaksi antara perawat dengan pasien. Perawat harus mengikutsertakan klien dalam pengambilan pengambilan keputusan, dikarenakan hal tersebut termasuk dalam hak pasien. Perawat dapat membantu klien dalam menentukan keputusan yang akan diambil dengan dilandasi oleh pengetahuan-pengetahuan dan hasil dari pemikiran yang kritis sehingga dapat menentukan keputusan terbaik dalam menyelesaikan suatu masalah.

Keterlibatan pasien dalam mengambil keputusan klinis merupakan upaya dalam pemberdayaan klien untuk meningkatkan tingkat kemandirian klien. Disini peran perawat yaitu memfasilitasi dan memberdayakan potensi internal klien. Dengan demikian diharapkan dari interaksi tersebut dapat menguntungkan klien dan tidak memiliki efek yang negative terhadap klien.

\section{Metode}

Metode yang digunakan adalah metode literature review. Metode yang berlandaskan teori dari buku, koran, majalah, jurnal, serta $e$-book yang memuat segala informasi mengenai partisipasi pasien dalam mengambil keputusan klinis. Di mana dibutuhkan peran perawat untuk memfasilitasi pasien dalam pengambilan keputusan. Sumber juga diambil mengenai 
pentingnya berpikir kritis perawat dalam melaksanaka proses keperawatan yang akhirnya akan megambil keputusan klinis keperawatan dengan tidak berdampak negative pada pasien. Sumber-sumber yang diambil dengan tahun paling lama yaitu 2012.

\section{Hasil}

Dalam mengambil keputusan klinis perawat perlu mempunyai ketrampilan untuk berpikir kritis. Berpikir kritis dapat melandasi bagaimana seorang perawat dalam mengidentifikasi dan mempertimbangkan keputusan yang baik terhadap pasien. Dengan memiliki kemampuan tersebut perawat dapat memberikan pemahaman pada pasien untuk terlibat dalam menentukan keputusan yang terbaik. Kerjasama antara perawat dan pasien merupakan komponen utama dalam pemberian asuhan keperawatan, pengambilan keputusan merupakan bagian dari asuhan keperawatan, sehingga pengambilan keputusan dalam proses keperawatan harus melibatkan pasien dan keluarganya.

Pengambilan keputusan klinis merupakan bagian dari kolaborasi klien dan perawat. Sehingga seorang perawat dituntut mampu untuk melakukan pengambilan keputusan dengan melibatkan klien, perawat bukan pengambil keputusan tunggal akan tetapi sebagai fasilitator bagi klien. Mengambil keputusan dengan melibatkan pasien diharapkan perawat akan mampu mengidentifikasi nilai-nilai budaya yang dianut oleh klien, dengan begitu akan menghasilkan keputusan yang baik dan tidak merugikan klien.

Peran perawat disini yaitu untuk memfasilitasi klien dan memberdayakan potensi internal klien untuk membantu klien agar mandiri dalam menentukan yang terbaik bagi dirinya. Tingkat kemandirian ini akan dicapai jika pasien dan keluarga mampu mengambil keputusan dengan baik dan tepat dalam memilih assuhan dan bantuan terkait kondisinya. Sehingga diperlukan peran aktif pasien dan keluarga daalam pengambilan keputusan klinis tersebut. Dalam beberapa penilitian disebutkan bahwa tugas perawat pada saat pengambilan proses pengambilan keputusan ini adalah sebagai fasilitator untuk memberikan fasilitas dan dukungan pada klien

Ketepatan pengambilan keputusan akan di pengaruhi oleh kompetensi perawat, kemampuan berkomunikasi, lingkungan serta budaya. Penting bagi perawat untuk 
selalu meningkatkan kapasitas dirinya dalam pemberian asuhan keperawatan hal ini akan meningkatkan kepercayaan masyarakat terhadap perawat yang selanjutnya akan meningkatkan profesionalisme perawat.

Dengan mengambil keputusan klinis yang mengikutsertakan pasien, maka akan mudah untuk menyelesaikan masalah tertentu dengan pilihan-pilihan keputusan yang terbaik. Dalam kolaborasi antara perawat-klien, perawat berperan sebagai leader dalam pengambilan keputusan klinis keperawatan. Pengalaman pasien dalam keterlibatan proses keperawatan harus dihargai dan dapat digunakan sebagai dasar dalam pengambilan keputusan klinis. Perawat harus memahami kebutuhan pasien dalam setiap proses keperawatan, sehingga hubungan perawat klien dalam pengambilan keputusan dalam dilakukan pada setiap proses keperawatan.

\section{Pembahasan}

Keputusan klinis adalah suatu proses yang meliputi diagnosis klinis, penilaian dan keputusan tentang apa yang harus dilakukan (Ennis 1996). Proses pengambilan keputusan dalam praktik klinik keperawatan merupakan serangkaian keputusan yang dibuat oleh perawat dalam interaksinya dengan pasien mengenai jenis pengamatan yang akan dilakukan dalam situasi yang di alami klien (pengkajian keperawatan) perumusan diagnosa keperawatan rencana tindakan keperawatan yang harus diambil, tindakan keperawatan yang akan diambil serta evaluasi (Dianan Catarina. 2009, Jan Florin. 2007, Mehee, 2014). Perlu difahami bahwa istilah keputusan klinis merupakan pilihan dianatara alternatif yang ada sebagai upaya pemecahan masalah (Dowei, 1993).

Definisi lain dijelaskan bahwa pengambilan keputusan klinis keperawatan merupakan serangkaian keputusan yang dibuat oleh perawat, dalam interaksi dengan klien mengenai pengkajian yang didapat dari klien, evaluasi data yang diamati, variasi diagnosa yang muncul serta tindakan keperawatan yang harus diambil (Gan Florin. 2007, Mehee. 2014).

Pelaksanaan proses keperawatan tersebut membutuhkan kemampuan perawat dalam mengambil keputusan klinis dengan tetap mengedepankan nilai disiplin etik dan bioetik keperawatan. Sehingga dalam proses ini perawat harus melibatkan pasien. Keterlibatan klien yang dimaksud dalam pengambilan keputusan ini adalah sebagai upaya pemberdayaan klien sehingga meningkatkan tingkat kemandirian klien. 
Membina hubungan antara perawat dan klien didasarkan pada hubungan yang percaya, menghormati dan hubungan profesianal dengan mengedepankan nilai etik dan disiplin profesi. Selama praktek, profesional keperawatan menghadapi sejumlah situasi yang berbeda melibatkan klien dan pemenuhannya yang berbeda. Proses pengambilan keputusan klinis merupakan komponen penting dalam proses keperawatan (Diana Catarina, 2009), sehingga dibutuhkan kemampuan perawatan yang baik karena jika perawat memiliki pengetahuan yang terbatas dikhawatirkan dapat menghambat perawat dalam memgambil keputusan klinis yang akan berdampak negatif terhadap klien. Dalam hal ini diperlukannya kemampuan berpikir kritis perawat.

Beberapa konsep yang digunakan dalam berpikir kritis dalam keperawatan adalah penalaran klinis, perumusan diagnostik, pengambilan keputusan penilaian, dan pemecahan maslah. Kemampuan berpikir kritis perawat dalam pengambilan keputusan klinis berhubungan erat dengan kemampuan berpikir kritis perawat dan pengalaman kerja mempunyai hubungan erat dengan kemampuan pengambilan keputusan klinis.
Berpikir kritis digambarkan sebagai "sebuah proses, tujuan untuk membuat keputusan yang masuk akal tentang apa yang harus percaya dan apa yang harus dilakukan". Pengambilan keputusan klinis adalah sebuah proses yang melibatkan kedua penalaran diagnostik dan penilaian klinis. Tindakan dalam ini tindakan diarahkan sebagai proses refleksi dari perawat maupun pasien (Jan Florin, 2007).

Kemampuan membuat keputusan masalah etis menjadi salah satu persyaratan bagi perawat untuk menjalankan praktik keperawatan professional. Pengambilan keputusan merupakan suatu pendekatan sistematis untuk menyelesaikan suatu masalah. Penilaian dan keputusan klinis sangat dibutuhkan untuk mendapatkan kualitas pelayanan yang optimal.

Pengambilan keputusan sangat
penting dalam menentukan asuhan
keperawatan kepada pasien. Perawat perlu mempertimbangkan banyak faktor yang berpotensi mempengaruhi proses pengambilan keputusan dalam memenuhi kebutuhan pasien (Cristine W. Nibbelink, 2017). Perawat harus mempunyai kemampuan yang baik untuk pasien maupun dirinya didalam menghadapi masalah yang menyangkut etika. Seseorang harus berpikir 
secara rasional, bukan emosional dalam membuat keputusan etis. Keputusan tersebut membutuhkan keterampilan berpikir secara sadar yang diperlukan untuk menyelamatkan keputusan pasien dan memberikan asuhan. Kemampuan membuat keputusan masalah etis menjadi salah satu persyaratan bagi perawat untuk menjalankan praktik keperawatan professional (Haryono, 2012).

Perawat pada semua tingkatan posisi klinis harus memiliki kemampuan menyelesaikan masalah dan mengambil keputusan yang efektif, baik sebagai pelaksana/staf maupun sebagai pemimpin. Guyatt (Agung pranoto. 2013) menjelaskan bahwa asuhan yang berdasarkan evidence base pengambilan keputusan harus melibatkan pasien. Sehingga penting bagi perawat untuk mampu mengambil keputusan dengan baik, cepat dan akurat. Perawat perlu memahami hubungan nilai-nilai budaya yang dianut klien saat mengambil keputusan klinis agar tidak bertolak belakang dan dapat menyebabkan dampak yang negative terhadap klien. Oleh karena itu dalam pengambilan keputusan klinis perlu adanya partisipasi klien.

\footnotetext{
Pemberian asuhan keperawatan harus memeperhatikan klien dengan memberikan penghargaan individu meliputi
}

preferensi, keperluan nilai-nilai, memastikan bahwa dan semua pengambilan keputusan klinik telah mempertimbangkan dari semua nilai-nilai yang diingini pasien (Comite if quality of health institute of medicine 2001).

Pemberian asuhan keperawatan kepada pasien, perawat harus mampu melibatkan pasien dalam setiap proses keperawatannya. Pengambilan keputusan yang tepat menggunakan suatu pendekatan yang sistematis terhadap hakekat suatu masalah dengan pengumpulan fakta-fakta dan data. Dalam menentukan alternatif yang matang untuk mengambil suatu tindakan yang tepat didasarkan pada kriteria tertentu atas dua atau lebih alternatif yang sesuai (George R. Terry, 2019). Hubungan profesional perawat dan klien didasarkan pada pemahaman bahwa klien adalah orang yang paling tepat untuk membuat keputusan. Dalam hal ini, perawat perlu menjalin hubungan terapeutik dengan pasien, dengan membangun hubungan tersebut diharapkan perawat dapat menggali data dengan mengumpulkan faktafakta dari pasien dengan tujuan untuk memenuhi pertimbangan dalam mengambil keputusan klinis.

Sama halnya saat perawat akan
melakukan tindakan, perawat perlu
berinteraksi pada klien untuk memastikan


apakah klien setuju dengan keputusan (tindakan) yang diambil. Mendapatkan persetujuan dalam melakukan tindakan dan pasien atau keluarga pasien berhak menolak tindakan dengan menandatangani pernyataan penolakan tindakan. Prinsip tersebut merupakan prinsip perawat saat akan melakukan suatu tindakan. Sebelum melakukan tindakan, perawat harus memberitahukan tindakan yang akan dilakukan kepada pasien. Hal ini sesuai dengan prinsip menghargai pasien sebagai orang yang bermartabat dan mampu untuk menentukan apa yang terbaik bagi dirinya sendiri (Autonomy).

Pengambilan keputusan yang tepat akan meningkatkan dan melatih kemandirian pasien dalam asuhannya serta membantu pasien untu menentukan pilihan bantuan yang tepat sesuai dengan kondisinya. Pasien yang mandiri akan menurunkan beban kerja perawat sehingga pelayanan keperawatan akan lebih efektif dan efisien dalam penggunaan sumber daya. Untuk itu dibutuhkan banyak dukungan dalam implementasi dari diskusi dalam mengambil keputusan klinis ini.

\section{Penutup}

Proses pengambilan keputusan merupakan sebuah hasil keputusan yang dibuat dari perawat dalam mengikutsertakan klien, perlu adanya interaksi antara perawatklien dalam pengambilan keputusan klinis keperawatan. Pengambilan keputusan klinis keperawatan dapat dilakukan dalam setiap proses keperawatan, tugas perawat pada saat proses pengambilan keputusan ini adalah sebagai fasilitator untuk memberikan fasilitas dan dukungan pada pasien, pengambilan keputusan klinis dengan melibatkan pasien akan meningkatkan tingkat kemandirian untuk pasien, pengambilan keputusan klinis diperlukan kemampuan berfikir kritis bagi perawat. Tetapi pengambilan keputusan masih belum sepenuhnya dilakukan bersama antara perawat-klien. Perawat masih berperan sebagai pengambil keputusan tunggal. Sehingga dibutuhkan pemahaman lebih lanjut terkait dengan pengambilan keputusan klinis keperawatan dengan harapan peran perawat akan lebih terlihat nyata sebagai pemberi asuhan yang akan meningkatkan kepercayaan masyarakat terhadap profesi keperawatan. 


\section{Daftar Pustaka}

Daniel, D., Erika, K. A., \& Rachmawaty, R. (2020). Sistim Pendukung dalam Pembuatan Keputusan Klinis Perawat di Ruang Rawat Inap: Literature Review (Support System In The Making Of Nursing Clinical Decisions In The Hospital Room: A Literature Review). Jurnal Ilmu Kesehatan, 8(2), 173181.

Khairina, I., Malini, H., \& Huriani, E. (2018). Faktor-Faktor yang Berhubungan dengan Pengambilan Keputusan Perawat Dalam Ketepatan Triase Di Kota Padang. Indonesian Journal for Health Sciences, 2(1), 1-6.

Larasati, T. A. (2019). Komunikasi Dokter-

Pasien Berfokus Pasien pada Pelayanan Kesehatan Primer. Jurnal Kedokteran Universitas Lampung, 3(1), 160-166.

Mariana, D. (2019). Hubungan Kualitas Pelayanan Keperawatan Rawat Inap dengan Proses Pengambilan Keputusan Pasien Untuk Memilih Rumah Sakit. Babul Ilmi Jurnal Ilmiah Multi Science Kesehatan, 10(2).

Pangaribuan, R. (2017). Presepsi Perawat Terhadap Prinsip-prinsip Etik Dalam Pelaksanaan Tindakan Keperawatan di ICU Rumah Sakit TK. II Putri Hijau Medan.
Jurnal Riset Hesti Medan Akper Kesdam I/BB Medan, 1(1), 37-44.

Pashar, I., \& Dwiantoro, L. (2020). Pengaruh Empowerment Terhadap Pengambilan Keputusan Perawat: Kajian Literature Review. Journal of Holistic Nursing Science, 7(2), 124-132.

Rahayu, C. D., \& Mulyani, S. (2020). Pengambilan Keputusan Klinis Perawat. Jurnal Ilmiah Kesehatan, 10(1), 111.

Silfa, A. B., Hardisman, H., \& Pabuti, A. (2018). Analisis Hubungan Pengetahuan dan Persepsi Pasien dengan Partisipasi Pasien di Instalasi Paviliun Ambun Pagi RSUP DR. M. Djamil Padang Ditinjau dari Aspek Hukum Keselamatan Pasien. Jurnal Kesehatan Andalas, 7(2), 160-169.

Simamora, R. H. (2005). Hubungan Persepsi Perawat Pelaksana Terhadap Penerapan Fungsi Pengorganisasian Yang Dilakukan Oleh Kepala Ruangan Dengan Kinerjanya Diruang Rawat Inap RSUD Koja Jakarta Utara (Doctoral dissertation, Tesis FIK UI, Tidak dipublikasikan).

Simamora, R. H. (2019). Menjadi perawat yang: CIH'HUY. Surakarta: Kekata Publisher. 
Sudono, B., Arumawati, D. S., \& Haris, R. A. (2017). Gambaran kemampuan berpikir kritis perawat primer dalam pelaksanaan asuhan keperawatan di Rumah Sakit Islam Surakarta. Jurnal Ilmu Keperawatan Indonesia (JIKI), 10(1).

Sutriyanti, Y., \& Mulyadi, M. (2019). Analisis Faktor-Faktor yang Mempengaruhi Penerapan Berpikir Kritis Perawat dalam Melaksanakan Asuhan Keperawatan di Rumah Sakit. Jurnal Keperawatan Raflesia, 1(1), 21-32. 